\title{
The Vitamin E Distribution in Serum, Liver, Adipose and Muscle Tissues in the Pig during Depletion and Repletion
}

\author{
By Marianne Jensen, Arne Lindholm and Juhani Hakkarainen \\ Department of Medicine and Surgery and Department of Clinical Nutrition, Faculty of Veterinary \\ Medicine, Swedish University of Agricultural Sciences, Uppsala, Sweden.
}

Jensen, M., A Lindholm and J. Hakkarainen: The vitamin $\mathbf{E}$ distribution in serum, liver, adipose and muscle tissues in the pig during depletion and repletion. Acta vet. scand. 1990, 31, 129-136. - This study was designed to examine the storage capacity for vitamin $\mathrm{E}$ in liver, adipose tissue and skeletal muscle of growing pigs during a period of supplementation and of depletion. Therefore, biopsy specimens of these tissues and samples of serum were frequently taken from 7 pigs throughout the experimental period.

After a 7-week period on a diet highly supplemented with vitamin $E(405 \mathrm{mg} / \mathrm{kg})$, a significant increase $(p<0.001)$ in the concentration of this vitamin was observed in all tissues sampled. The highest level $(102.9 \pm 26.2 \mathrm{mg} / \mathrm{kg})$ was observed in the liver. After 2 days of depletion the concentration of vitamin $E$ in the liver had fallen by $80 \%$, whereas the concentration in the fat and muscle remained unchanged during 1 week of depletion.

The serum vitamin $E$ value rose significantly $(p<0.001)$ after 1 week on the supplemented diet and then remained at about $7 \mathrm{mg} / \mathrm{l}$ throughout the supplementation period and decreased $(p<0.001)$ after 2 days on a nonsupplemented diet.

Generally, the serum vitamin E levels among growing pigs are between 2 and 3 $\mathrm{mg} / \mathrm{l}$. The results show that the serum and liver values were correlated when the serum level was within this range. Moreover, it is clearly demonstrated that the concentrations of vitamin $E$ in serum and liver reflect the immediate nutritional status of the animal, whereas the vitamin concentrations in adipose and skeletal muscle tissue reflect its long-term nutritional history.

diet; supplementation; concentration; serum; biopsy specimens; adipose tissue; skeletal muscle; myocardium.

\begin{abstract}
Introduction
Vitamin $\mathrm{E}$ is known to be a potent antioxidant in vitro (Dam 1944) and to act as a free radical scavenger in vivo, thus protecting cell- and subcellular membranes from damaging peroxidation (Machlin 1980). In addition to its antioxidant properties, it has been suggested that vitamin $\mathrm{E}$ may have structural functions in biological membranes (Lucy 1972).
\end{abstract}

The vitamin $\mathrm{E}$ status of an animal can be assessed by measuring the concentration of this vitamin in serum and various tissues. In several experiments it has been shown that the serum vitamin $\mathrm{E}$ concentration reflects the daily intake of this compound, whereas the concentrations in skeletal muscle and adipose tissue reflect the intake over a period of time (Bieri 1972, Lehman 1979, Machlin et al. 1979, Ronéus et al. 1986, Jensen et al. 1988a).

In a previous study (Jensen et al. 1988a) it was found that the liver had a remarkable storage capacity for vitamin E. However, 
the data indicated that the liver had non long-term storage capacity of vitamin $\mathrm{E}$. Since the liver is a target organ for hepatosis dietetica (HD), a major symptom within the vitamin $\mathrm{E}$ and selenium deficiency (VESD) syndrome in pigs (c.f. Lannek \& Lindberg 1975, Van Vleet 1980), it is of great interest to study the rate of accumulation and depletion of vitamin $E$ in the liver.

The primary objectives of the present experiment was therefore to study the vitamin $\mathrm{E}$ storage capacity in the liver, under a period of supplementation and depletion, and to confirm the results from the previous experiment. The storage capacity for vitamin $E$ in adipose and muscle tissues with different oxidative capacities was also evaluated.

In addition, a possible relationship between the vitamin $E$ concentration in serum and liver was investigated.

\section{Materials and methods Animals}

A litter consisting of 7 weaned crossbreed (Swedish Yorkshire $\mathrm{x}$ Swedish Landrace $\mathrm{x}$ Hampshire) pigs was used in this study. Their age at start of the experiment was 7 weeks and their mean weight $16 \mathrm{~kg}$. The hogs were kept in the same stable in conventional pens with a concrete floor and with cut newspaper as bedding.

\section{Experimental design and diets}

The vitamin $E$ was supplemented to the feed as $d 1-\alpha$-tocopheryl acetate. Therefore, as concerns the dietary intake, the term vitamin $E$ is referred to $\mathrm{dl}-\alpha$-tocopheryl acetate.

Since $\alpha$-tocopherol is the predominating isomer in the body, the expression vitamin $E$ is equivalent to $\alpha$-tocopherol when the tissue concentrations are discussed.

For a period of 4 weeks (depletion 1) the animals were fed a basal diet low in vitamin $E$, containing $16 \mathrm{mg}$ of dl- $\alpha$-tocopheryl acetate
Table 1. Composition of the basal diet ${ }^{\mathrm{a}}$.

\begin{tabular}{lc}
\hline Ingredient & $\begin{array}{c}\text { Percentage } \\
\text { of diet }\end{array}$ \\
\hline Ground barleyb & 78.7 \\
Dried skim milk & 18.0 \\
Limestone & 0.5 \\
Dicalcium phosphate & 1.4 \\
Sodium chloide & 0.4 \\
Vitaminc and mineral mix $^{\mathrm{d}}$ & 1.0
\end{tabular}

aCalculated analysis: $\mathrm{CP}, 24.8: \mathrm{MJ} \mathrm{ME} / \mathrm{kg}, 12.5$; lysine, $0.8 \%$; digestible lysine, $0.7 \%$; $g$ digestible lysine/MJ, 0.56; Ca, $0.83 \%$; P, $0.67 \%$.

'Containing a total of $41 \mathrm{mg}$ of vitamin E/kg, corresponding to $16 \mathrm{mg}$ of d1- $\alpha$-tocopheryl acetate equivalents $/ \mathrm{kg}$.

'Provided (per 1,000 kg of feed): Vitamin A, 5,000,$000 \mathrm{IU} ; \mathrm{D}_{3}, 1,000,000 \mathrm{IU}$; riboflavin, $3 \mathrm{~g}$; niacin, 18 $\mathrm{g}$; pyridoxine, $2 \mathrm{~g}$; vitamin $\mathrm{B}_{12}, 20 \mathrm{mg}$.

${ }^{\mathrm{d}}$ Contained (per $1,00 \mathrm{~kg}$ of feed): $\mathrm{Ca}, 6 \mathrm{~g}$; $\mathrm{Cu}, 9 \mathrm{~g}$; $\mathrm{Zn}, 121 \mathrm{~g} ; \mathrm{Mn}, 20 \mathrm{~g} ; \mathrm{Fe}, 74 \mathrm{~g}$; I, $100 \mathrm{mg}$.

equivalents $/ \mathrm{kg}$ feed (Table 1$)$. This was followed by a 7-week period (supplementation) on the same diet but now supplemented with $405 \mathrm{mg}$ of dl- $\alpha$-tocopheryl acetate $/ \mathrm{kg}$ of feed. Finally, the pigs were again fed the basal diet for 1 week (depletion 2), after which the experiment was terminated.

The concentration of PUFA in the diet was $12.7 \mathrm{~g} / \mathrm{kg}$ and the selenium concentration was $0.1 \mathrm{ppm}$. The pigs were fed according to the SLU feeding scale (Andersson 1985). The animals were inspected at least twice daily for their clinical state of health and the weekly body weight gain was noted. Blood samples were collected once a week throughout the experimental period, and an additional sample was taken during depletion 2 .

Surgical biopsy specimens were taken from the liver, adipose tissue and the deep portion of the biceps femoris in all animals at the end of depletion 1, at the end of supplementation, after 2 days and at the end of depletion 2 , i.e. at slaughter. In order to compare the vitamin $\mathrm{E}$ concentration in highly oxidative muscles with that in a moderately oxidative 


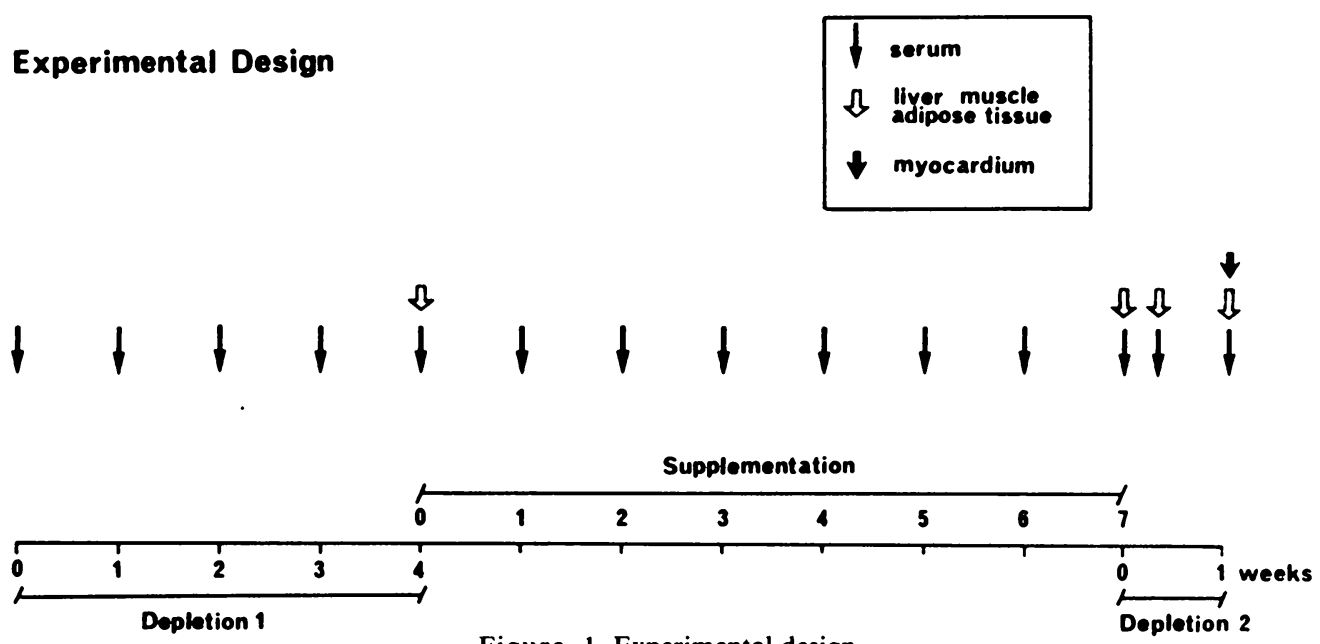

Figure 1. Experimental design.

muscle, samples were obtained from the vastus medius muscle and the myocardium at slaughter (Fig. 1).

\section{Sampling procedure}

Blood samples from the external jugular vein were drawn into $10 \mathrm{ml}$ vacutainer tubes and centrifuged at a force of $1,600 \times \mathrm{g}$ for 10 $\min$. The serum was separated and stored at $-20^{\circ} \mathrm{C}$ until analysed. The tissue samples were obtained under general anaesthesia by a surgical procedure as described previously (Jensen et al. 1988a). Briefly, a piece of about $3 \mathrm{~g}$ was taken through a skin incision from the midportion of the muscle belly of the biceps femoris. After an incision at the linea alba, specimens (approximately $2 \mathrm{~g}$ ) were cut from the cranial lobe of the liver, and specimens of subcutaneous fat were taken from a site at the linea alba.

Samples of the papillary muscle of the myocardium and of the midportion of vastus medius muscle were obtained at slaughter.

\section{Measurements of vitamin $E$}

The concentrations of vitamin $\mathrm{E}$ and its isomers in serum and tissues were determined by high pressure liquid chromatography (HPLC) as described previously (Jensen et al. 1988a). As shown in the latter study, it was sufficient to express the vitamin $\mathrm{E}$ concentration as $\mathrm{mg} / \mathrm{l}$ serum.

Thus, the concentration of vitamin $\mathrm{E}$ is expressed as $\mathrm{mg} / \mathrm{l}$ serum or as $\mathrm{mg} / \mathrm{kg}$ wet tissue.

\section{Measurements of serum lipids}

The serum lipids were assayed weekly by the method of Epstein et al. (1972) and the mean $\mathrm{CV}$ of the determinations was $\mathbf{3 . 1 \%}$.

\section{Statistical methods}

SAS procedures (SAS 1985) were used for statistical analyses. Two-way analyses of variance, with weeks and animals regarded as classes, were applied to the concentrations of vitamin $\mathrm{E}$ in serum and tissues. Linear regression and analysis of covariance were used to evaluate the relationship between the vitamin $\mathrm{E}$ concentrations in serum and liver. The differences in the vitamin $\mathrm{E}$ concentration between the biceps femoris muscle, the vastus medius muscle and the myocardium. were assessed by the paired Student's test. 
The results are given as mean values $\pm \mathrm{SD}$ unless otherwise indicated.

\section{Results}

\section{Clinical state of health}

Normal body weight gain was noted in all pigs throughout the experimental period.

All animals remained healthy, except 1, which succumbed as a result of anaesthesia at the end of supplementation.

\section{Serum vitamin E concentrations}

In addition to the prevalent isomer $\alpha$-tocopherol, traces of $\alpha$-tocotrienol were found in the majority of the samples.

During depletion 1 the vitamin E values remained at the same low level, ranging from 0.27 to $1.08 \mathrm{mg} / \mathrm{l}$ serum.

During the supplementation there was a rapid increase in the vitamin $E$ concentration and as early as after 1 week the serum values had risen more than seven-fold $(p<0.001)$. As shown by the analysis of variance, no further increase in the serum values occurred during the remaining 6 weeks of supplementation, indicating that the serum was saturated with vitamin $E$. At this time the vitamin E concentration ranged from 4.82 to 10.23 $\mathrm{mg} / \mathrm{l}$.

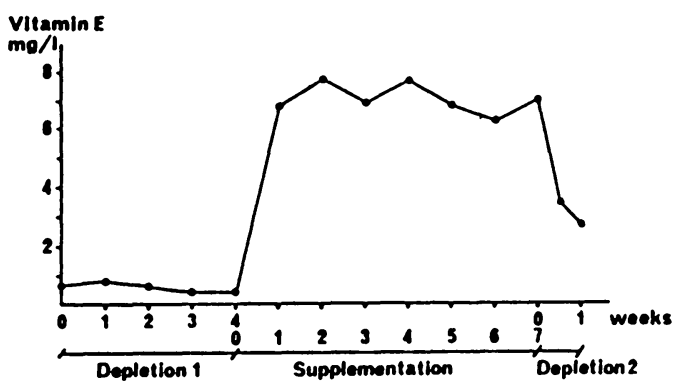

Figure 2. Mean weekly serum vitamin E concentrations in all pigs, throughout the experimental period. Note the significant increase $(p<0.001)$ in the vitamin $E$ concentration after 1 week of supplementation and the rapid drop $(\mathrm{p}<0.001)$ after 2 days of depletion.
During depletion 2, a significant decrease $(p<0.001)$ in the concentration of vitamin $E$ was observed after 2 days on the basal diet. On termination of the experiment a further decrease of the concentration was noted, the mean value now being $2.64 \pm 0.35 \mathrm{mg} / \mathrm{l}$ (Fig. 2).

The SE of the mean difference as obtained at analysis of variance was 0.46 .

\section{Serum lipid concentrations}

The total serum lipid concentration did not change with time. The values ranged from 1.64 to $4.06 \mathrm{~g} / \mathrm{l}$.

\section{Tissue vitamin E concentrations}

In all tissues the dominating isomer was $\alpha$ tocopherol. The isomer $\alpha$-tocotrienol was found in a few samples of liver and skeletal muscle in an amount of less than $10 \%$ and of adipose tissue in an amount of up to $10 \%$.

Liver. A significant increase $(\mathrm{p}<0.001)$ in the vitamin $\mathrm{E}$ concentration in the liver was observed during the 7 weeks of supplementation. The value rose precipitously from 0.76 \pm 0.15 to $102.93 \pm 26.22 \mathrm{mg} / \mathrm{kg}$. During depletion 2, the vitamin $\mathrm{E}$ concentration decreased markedly. After 2 days of depletion the value had dropped to $17.82 \pm 3.10$ $(p<0.001)$ and after 7 days, on termination of the experiment it was still lower, $6.03 \pm$ $0.92 \mathrm{mg} / \mathrm{kg}$ (Fig. 3).

The SE of the mean difference as obtained at the analysis of variance was $\mathbf{6 . 8 0}$.

Adipose tissue. In the adipose tissue a significant increase $(p<0.001)$ in the vitamin concentration took place from the beginning to the end of the supplementation. The concentration of vitamin $E$ increased about tenfold, from $2.77 \pm 0.87$ to $31.59 \pm 10.82$ $\mathrm{mg} / \mathrm{kg}$. 


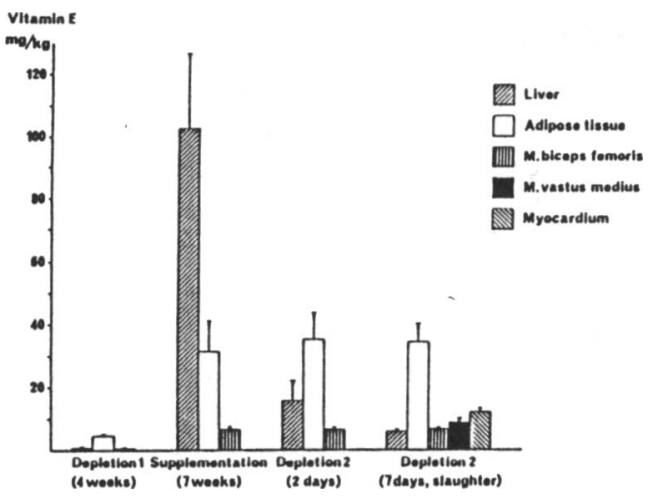

Figure 3. Tissue concentrations of vitamin $E$ (mean $\pm \mathrm{SD}$ ) in all pigs, throughout the experimental period. At the end of supplementation there was a significant increase $(p<0.001)$ in the vitamin concentration in the liver, adipose tissue and skeletal muscle. The values remained at this level in the fat and muscle tissues but decreased $(p<0.001)$ in the liver after only 2 days of depletion.

During depletion 2 there was no decrease in the vitamin $E$ value (Fig. 3).

The SE of the mean difference as observed from the analysis of variance was 3.44 .

Skeletal muscle. The biceps femoris exhibited a pattern similar to that of adipose tissue, with a significant $(p<0.001)$ increase in the concentration of vitamin $\mathrm{E}$ from the beginning to the end of supplementation. During this period the value rose from $0.50 \pm$ 0.23 to $6.77 \pm 0.99 \mathrm{mg} / \mathrm{kg}$. As in the case of adipose tissue the vitamin $E$ concentration remained at the same level during depletion 2 (Fig. 2). The SE of the mean difference as obtained at analysis of variance was $\mathbf{0 . 3 5}$.

At slaughter, the vitamin $\mathrm{E}$ concentration was significantly higher $(9.05 \pm 1.44$ $\mathrm{mg} / \mathrm{kg}$ ) in the vastus medius than in the biceps femoris $(p<0.05)$.

Myocardium. At the end of the experiment the vitamin $\mathrm{E}$ concentration in the myocardium was $13.60 \pm 1.52$ and significantly $(p<0.05)$ higher than in the skeletal muscles.
Relationship between the concentration of vitamin $E$ in liver and serum

The linear regression analyses revealed a correlation between the serum and liver values both at the end of the depletion $1(r=0.82$, $\mathrm{p}<0.05$ ) and at the end of depletion 2 $(r=0.84, p<0.05)$. On the former sampling occasion the serum values were about $1 \mathrm{mg} / \mathrm{l}$ and on the latter occasion about $3 \mathrm{mg} / \mathrm{l}$. As described above, the serum value showed a plateau, and serum thus seems to be saturated with vitamin $E$ at a mean level of about 7 $\mathrm{mg} / \mathrm{l}$. This finding may explain why the liver and serum values are not correlated when the value in the liver is very high.

The analysis of covariance revealed a negative intercept when the serum vitamin $\mathrm{E}$ concentration was zero, indicating a nonlinear relationship between these two tissues.

\section{Discussion}

The distribution of vitamin $\mathrm{E}$ takes place throughout the body, with the highest concentration in the adrenals, ovaries, liver, spleen and plasma, as measured $12 \mathrm{~h}$ after intragastric administration of $\mathrm{dl}$ - $\alpha$-tocopheryl acetate in rats (Gallo-Torres \& Miller 1971). The data obtained in the present study show that in the pig, the liver has a very large capacity for short-term storage of vitamin $E$, thus confirming the result from a previous study (Jensen et al. 1988a).

After 7 weeks of the supplemented diet the concentration of vitamin $\mathrm{E}$ was about 3 times higher in the liver than in adipose tissue. In this respect the pig differs from the rat (Bieri 1972), guinea pig (Machlin et al. 1979) and mink (Työppönen et al. 1984), all of which have their peak values in fat.

After only 2 days of depletion the vitamin $\mathrm{E}$ concentration fell by $80 \%$ in the liver. This rapid loss of vitamin $E$ from the liver during depletion may to some extent be referred to the large amount of blood in this organ, sin- 
ce it is known that the daily intake of vitamin $\mathrm{E}$ is well reflected in the serum (Simesen et al. 1979). Moreover, the large interindividual variations in the vitamin content of the liver might be due to differences in the amounts of lipids in the organ.

On supplementation with $405 \mathrm{mg}$ dl- $\alpha$-tocopheryl acetate, the serum vitamin $E$ level rose precipitously within 1 week, and then reached a plateau, indicating saturation at a mean level of $7 \mathrm{mg} / \mathrm{l}$. When pigs were given lower supplementary doses of vitamin $\mathrm{E}$ a plateau was reached within 3 to 4 weeks (Jensen et al. 1988a). Thus, in practice, a high daily dose of vitamin $\mathrm{E}$ given orally for 1 week only will result in a rapid increase in the serum vitamin $\mathrm{E}$ concentration.

In addition, the rapid rate at which both the serum and liver lose vitamin E during depletion show that daily intake is necessary in order to maintain the vitamin concentration in these tissues.

Rousseau et al. (1957) proposed that the liver storage of tocopherol might be estimated from plasma tocopherol concentrations in pigs. The data obtained in the present study show that such an estimation is feasible only when the serum vitamin $E$ is within a range of $1-3 \mathrm{mg} / \mathrm{l}$. Supplementation of $25 \mathrm{mg} / \mathrm{kg}$, which is often used in commercially available diets, will result in a serum vitamin $\mathrm{E}$ concentration of 2 to $3 \mathrm{mg} / \mathrm{l}$ (Jensen 1989). The concentration of vitamin $\mathrm{E}$ in the serum will therefore reflect the concentration in the liver when growing pigs are on a standard feeding scale, but not when they are recieving a highly supplemented diet as used in the present experiment.

In pigs, the addition of $15 \mathrm{mg} \mathrm{dl}$ - $\alpha$-tocopheryl acetate/ $\mathrm{kg}$ feed was found to be sufficient to maintain the tocopherol stores in the body fat at an unchanged level (Hakkarainen et al. 1978).

As regards the rate of loss of vitamin $E$ from the adipose tissue and skeletal muscle, there was no decrease in these tissues similar to that observed in the liver during 1 week of depletion. However, in the previous study (Jensen et al. 1988a) it was shown that a considerable amount of vitamin was mobilized from the fat and muscle tissues during 7 weeks of depletion. Thus, the mobilization of vitamin $\mathrm{E}$ from the adipose and skeletal muscle tissues will occur in the interval between 2 and 7 weeks after the start of depletion. The concentration of vitamin $\mathrm{E}$ in these tissues will therefore reflect the long-term nutritional history of an animal rather than the immediate nutritional status.

The cardiac muscle, an active muscle with a high oxidative capacity, had a higher vitamin E concentration than the skeletal muscles sampled. Analogously, the vastus medius muscle with its higher oxidative capacity had a higher concentration of vitamin $E$ than the biceps femoris. These findings are in accordance with previous observations in pigs (Jensen et al. 1988b). Interestingly, in rats it has been shown that the phospholipid content of the myocardium is higher than that of skeletal muscle (Narayan et al. 1975). Since vitamin $\mathrm{E}$ both protects the phospholipidcontaining biological membranes from free radical damage (Machlin 1980) and fulfills a physico-chemical role in these membranes (Lucy 1972), it seems very probable that the myocardium contains more vitamin $E$ than skeletal muscle. In muscle tissue the concentration of vitamin E apparently varies according to the need for antioxidant protection. In conclusion, the porcine liver has a very high short-term storage capacity for vitamin E. The concentrations of vitamin $\mathrm{E}$ in the liver and serum reflect the immediate nutritional status of the pig, whereas those in fat and skeletal muscle reflect its long-term nutritional history.

Furthermore, measurements of vitamin $\mathrm{E}$ in 
serum will indicate the vitamin concentration in the liver, if the serum concentration ranges between 1 and $3 \mathrm{mg} / \mathrm{l}$.

\section{Acknowledgements}

This study was supported by grants from the Swedish Council for Forestry and Agricultural Research.

The authors wish to thank Professor Sune Persson and Docent Birgitta Essén-Gustavsson for critical reading of the manuscript.

\section{References}

Andersson $K$ : SLU-feeding scale for growing finishing pigs. Report from the Research Information Centre at the Swedish Univ. of Agric. Sci. 1985, 67, 2.

Bieri J: Kinetics of tissue $\alpha$-tocopherol depletion and repletion. Ann. N. Y. Acad. Sci. 1972, 203, 181191.

Dam H: Studies on vitamin E deficiency in chicks. J. Nutr. 1944, 27, 193-211.

Epstein E, Baginski ES, Zak B: Extraction of lipids from serum and measurement of total serum lipids. Ann. Clin. Lab. Sci. 1972, 2, 244-254.

Gallo-Torres $H E$, Miller $O N$ : Tissue uptake and metabolism of d, 1-3, 4- ${ }^{3} \mathrm{H}_{2}-\alpha$-tocopheryl nicotinate and $d, 1-\alpha$-tocopheryl-1', $2^{\prime}-{ }^{3} \mathrm{H}_{2}$ fallowing intravenous administration. Int. J. Vit. Nutr. Res. 1971, 41, 339-354.

Hakkarainen J, Lindberg $P$, Bengtsson $G$, Jönsson $L$ : Combined therapeutic effect of dietary selenium and vitamin $E$ on manifested VESD syndrome in weaned pigs. Acta vet. scand. 1978, 19, 285-297.

Jensen M, Hakkarainen J, Lindholm A, Jönsson L: Vitamin $E$ requirement of growing swine. $J$. Anim. Sci. 1988a, 66, 3101-3111.

Jensen M, Essen-Gustavsson B, Hakkarainen J: The effect of a diet with a high or low content of vitamin E different skeletal muscle and myocardium in pigs. J. vet. Med. A. 1988b, 35, 487-497.

Jensen M: The vitamin $\mathrm{E}$ concentration in pig muscle biopsies: A methodological study. J. vet. Med. A, 1989, 36, 354-360.

Jensen $M$ : The influence of regular physical activity on the cellmediated immunity in pigs. Acta vet. scand. 1989, 30, 19-26.
Lannek $N$, Lindberg $P$ : Vitamin $\mathrm{E}$ and selenium deficiencies (VESD) of domestic animals. Adv. vet. Sci. comp. Med. 1975, 19, 127-164.

Lehman J: Relationships among levels of alpha tocopherol in platelets, plasma and tissues of rats: Responses to graded levels of vitamin E. Nutr. Rep. Int. 1979, 20, 685-692.

Lucy JA: Functional and structural aspects of biological membranes: A suggested structural role for vitamin $\mathrm{E}$ in the control of membrane permeability and stability. Anuals of the N. Y. Acad. Sci. 1972, 203, 4-11.

Machlin LJ, Keating J, Nelson J, Brin M, Filipski R, Miller $O N$ : Availability of adipose tissue tocopherol in the guinea pig. J. Nutr. 1979, 109, 105109.

Machlin LJ: Vitamin E - A comprehensive treatise. Marcel Dekker Inc. New York 1980, vol 1.

Narayan KA, McMullen JJ, Butler DP, Wakefield $T$, Calhoun WK: Effect of exercise on tissue lipids and serum lipoproteins of rats fed two levels of fat. J. Nutr. 1975, 105, 581-587.

Ronéus B, Hakkarainen J, Lindholm A, Työppönen $J$ : Vitamin $E$ requirements of adult standardbred horses evaluated by tissue depletion and repletion. Equine vet. J. 1986, 18, 50-58.

Rousseau JE, Dicks MW, Teichman R, Helmboldt $C F$, Bacon EL, Prouty RM, Dolge KL, Eaton $H D$, Junherr EL, Beall $G$ : Relationships between plasma, liver and dietary tocopherol in calves, lambs and pigs. J. Anim. Sci. 1957, 16, 612-622.

SAS: SAS $^{\circledast}$ User's Guide: Statistics Version 5 Edition. SAS Inst. Inc. Cary, NC, 1985. 965 pp.

Simesen MG, Nielsen HE, Danielsen W, Gissel-Nielsen $G$, Hjarde $W$, Leth $T$, Basse A: Selenium and vitamin $E$ deficiency in pigs. Acta vet. scand. 1979, 20, 289-305.

Työppönen J, Hakkarainen J, Juokslahj T, Lindberg $P$ : Vitamin $\mathrm{E}$ requirement of mink with special reference to tocopherol composition in plasma, liver and adipose tissue. Amer. J. vet. Res. 1984, 45, 1790-1794.

Van Vleet JF: Current knowledge of selenium - vitamin $\mathrm{E}$ deficiency in domestic animals. J. Amer. vet. med. Ass. 1980, 176, 321-325. 


\section{Sammanfattning}

$E$ vituminets fördelning i olika vävnader hos gris under en period av utamning respektive tillskott.

Denna studie syftar till att bestämma lagringskapaciteten för vitamin E i lever, fettvävnad och skelettmuskulatur hos växande grisar. Djuren erhöll en basal diet med eller utan E-vitamintillskott $(405 \mathrm{mg} / \mathrm{kg}$ foder). Under försöksperioden togs frekventa väv- nads- och serumprover. E-vitamininnehállet i dessa bestämdes med hjälp av HPLC. Det konstateras att levern har störst förmága at inlagra vitamin E. Ett samband mellan E-vitaminkoncentrationen i lever och serum föreligger då E-vitaminhalten i serum är mellan 1-3 mg/l. Leverkoncentrationen kan således beräknas utifrån analyserade serumvärden.

(Received April 11, 1989; accepted June 30, 1989).

Reprints may be requested from: Marianne Jensen, Dep. of Medicine and Surgery. P. O. Box 7018, Swedish University of Agricultural Science, S-75007 Uppsala, Sweden. 